\title{
Peran Baitul Mal Langsa dalam Pengelolaan Zakat dan Infaq untuk Meningkatkan Pemberdayaan Masyarakat
}

\section{The Role of Baitul Mal Langsa in the Management of Zakat and Infaq to Improve Community Empowerment}

\author{
Jauwahir1), Heri Kusmanto2)* \& Isnaini1) \\ 1)Program Studi Ilmu Administrasi Publik, Program Pasca Sarjana, Universitas Medan Area, \\ Indonesia \\ 2)Fakultas Ilmu Sosial dan Ilmu Politik, Universitas Sumatera Utara, Indonesia
}

Diterima: 08 Juli 2021; Disetujui: 15 Desember 2021; Dipublish: 01 Januari 2022

\begin{abstract}
Abstrak
Penelitian ini bertujuan untuk mengetahui bagaimana mana peran Baitul Mal Kota Langsa dalam Mengelola Zakat dan Infaq untuk memberdayakan masyarakat kurang mampu yang diidentifikasi sebagai mustahik di Kota Langsa. Jenis penelitian ini adalah Field Research atau penelitian lapangan yang bersifat studi kasus, yaitu penelitian yang dilakukan secara intensif terinci dan mendalam terhadap suatu organisasi, lembaga atau gejala tertentudengan cara mengumpulkan keterangan yang diperlukan dengan jalan berkunjung kerumah atau ketempat orang-orang atau badan-badan yang akan diminta keterangannya. Pendekatan yang dilakukan dalam penelitian ini bersifat kualitatif yaitu penelitian yang perlu dilakukan seusai masalah diteliti secara kualitatif, tetapi belum terungkapkan penyelesaiannya. Penelitian ini terdiri dari data primer dan data sekunder. Data primer diperoleh dari hasil survey atau hasil wawancara mendalam dengan Kepala Baitul Mal, Sekretaris dan Staff atau pengurus yang merupakan kunci berlangsungnya kegiatan Penyaluran Zakat dan Infaq. Sedangkan dataset kunder diperoleh peneliti dari sumber yang sudah ada, seperti gambaran umum perusahaan, struktur organisasi, dan sebagainya. Hasil dari penelitian menunjukkan Baitul Mal memiliki peran untuk mengurus, mengelola, mengumpulkan, menyalurkan, serta mendayagunakan zakat. Pengumpulan zakat dilakukan dengan cara menerima atau mengambil dari orang yang mengeluarkan zakat (muzakki) berdasarkan pemberitahuan muzakki.
\end{abstract}

Kata Kunci: Pengelolaan Zakat Dan Infaq Untuk Pemberdayaan Masyarakat

\section{Abstract}

This study aims to find out what the role of Baitul Mal in Langsa City is in Managing Zakat and Infaq to empower underprivileged communities identified as mustahik in Langsa City. various ways and means. The meaning of infaq is also something that is spent for good. Infaq also does not have a time limit as well as large and small. This type of research is Field Research or field research that is case study, namely research that is carried out intensively in detail and in depth on an organization, institution or particular phenomenon by collecting the necessary information by visiting homes or places of people or agencies who information will be asked. The approach used in this research is qualitative, namely research that needs to be carried out after the problem is researched qualitatively, but the solution has not been revealed. This research consists of primary data and secondary data. Primary data is obtained from survey results or results of in-depth interviews with the Head of Baitul Mal, Secretary and Staff or management who are the key to the ongoing activities of Zakat and Infaq Distribution. Meanwhile, secondary datasets were obtained by researchers from existing sources, such as an overview of the company, organizational structure, and so on. The results of the study show that Baitul Mal has a role to take care of, manage, collect, distribute, and utilize zakat. The collection of zakat is carried out by receiving or taking from the person who issued the zakat (muzakki) based on the notification of the muzakki.

Keywords: Management of Zakat and Infaq for Community Empowerment

How to cite: Jauwahir, Kusmanto, H. \& Isnaini. (2022). Peran Baitul Mal Langsa dalam Pengelolaan zakat Dan Infaq Untuk Meningkatkan Peberdayaan Masyarakat. PERSPEKTIF, 11 (1): 250-261.

*Corresponding author:

E-mail: herikusmanto@usu.ac.id ISSN 2085-0328 (Print) ISSN 2541-5913 (online) 


\section{PENDAHULUAN}

Zakat adalah harta yang wajib dikeluarkan oleh seorang muslim atau badan usaha untukdiberikan kepada yang berhak menerimanya sesuai dengan syariat Islam (Undang-Undang Nomor 23 Tahun 2011, Pasal1, angka 2). Menunaikan zakat merupakan kewajiban bagi orang yang mampu sesuai dengan syariatIslam.

Zakat merupakan pranata keagamaan yang bertujuan untuk meningkatkan keadilan, kesejahteraan masyarakat dan penanggulangan kemiskinan. Dalam rangka meningkatkan dayaguna dan hasil usaha, zakat harus dikelola secara lembaga sesuai dengan syariat Islam, amanah, kemanfaatan, keadilan kepastian hukum, terintegrasi dana kuntabilitas sehingga dapat meningkatkan efektifitas dan efisiensi pelayanan dalam pengelolaan zakat.

Di Indonesia zakat diatur secara khusus pengelolaanya pada Undang-Undang Nomor 23 Tahun 2011 tentang Pengelolaan Zakat. Di dalam Undang-Undang tersebut disebutkan bahwa dalam rangka pelaksanaan pengelolaan zakat pada tingkat provinsi dan kabupaten/kota dibentuk BAZNAS provinsi dan BAZNAS kabupaten/kota. Dalam konteks kehidupan bernegara 2 (dua) lembaga pengelola zakat ini sangatlah berperan penting dalam melaksanakan pengelolaan dana zakat, keduanya merupakan lembaga yang akan menentukan keberhasilan pengelolaan potensi ekonomi masyarakat Indonesia dan berperan penting untuk mewujudkan syiar agama Islam. Sehingga 2 (dua) lembaga ini diharapkan mampu berkembang agar tujuan utama pengelolaan zakat dapat tercapai.

Dalam penjelasan pasal 15 UndangUndang Nomor 23 Tahun 2011 terkait dengan pengelolaan zakat pada tingkat Provinsi dan Kabupaten/Kota disebutkan, "Di Provinsi Aceh, penyebutan BAZNAS provinsi atau BAZNAS kabupaten/kota dapat menggunakan istilah Baitul Mal."Baitul Maladalah Lembaga DaerahNon-Struktura lyang diberi kewenangan untuk mengelola dan mengembangkan zakat, wakaf, harta agama dengan tujuan untuk kemaslahatan umat serta menjadi wali/wali pengawas terhadap anak yatim piatu dan/atau hartanya serta pengelolaan terhadap harta warisan yang tidak ada wali berdasarkan Syariat Islam.
Dasar hukum Baitul Mal di Provinsi Aceh ialah Undang-Undang Nomor 11 Tahun 2006 tentang Pemerintahan Aceh. Kemudian aturan tersebut diatur lebih lanjut dalam Qanun Aceh Nomor 10 Tahun 2007 tentang Baitul Mal yang menetapkan kedudukan Baitul Mal sebagai Lembaga Daerah. Dalam melaksanakan tugasnya Baitul Mal pada tingkat Provinsi dibantu oleh Sekretariat yang aturannya terdapat dalam Peraturan Menteri Dalam Negeri Nomor 18 Tahun 2008 tentang Pedoman Organisasi dan Tata Kerja Lembaga Keistimewaan Provinsi Aceh (termasuk Baitul Mal) yang menetapkan sekretariat Baitul Mal Aceh merupakan Satuan Kerja Perangkat Aceh dalam jabatan struktural pada tingkat Kabupaten/kota. Sedangkan sekretariat tingkat Kabupaten/Kota diatur dalam Peraturan Menteri Dalam Negeri Nomor37 Tahun 2009 tentang Pedoman Organisasi dan Tata Kerja Lembaga Keistimewaan Kabupaten/Kota Provinsi Aceh yang menetapkan Sekretariat Baitul Mal/Kota merupakan Satuan Kerja Perangkat Kabupaten/Kota dalam Jabatan Struktural.

Suatu kekhususan di Aceh ialah memberlakukan zakat sebagai salah satu sumber Pendapatan Asli Daerah (PAD) yang bersifat khusus. Tetapi walaupun sebagai PAD, zakat tidak dapat digunakan untuk membiayai pengeluaran yang telah di anggarkan dalam APBD, kecuali untuk penyaluran zakat yang sesuai dengan syariat Islam. Dalam hal pengelolaan zakat di Aceh, hingga saat ini telah terbentuk 23 Baitul Mal yang tersebar diseluruh Kabupaten/Kota se-Provinsi Aceh (http://pusat.baznas.go.id/ posko- aceh/ baitul- mal- aceh- bagian- dari- sistem pengelolaan- zakat- nasional/, diakses pada 16 Agustus 2018). Salah satunya ialah Baitul Mal Kota Langsa yang akan dijadikan sasaran dalam penelitian ini.

Menyoal perkara zakat, maka yang terpenting dan tidak boleh dilupakan adalah peran amil zakat selaku pengemban amanah dalam melakukan manajemen pengelolaan zakat. Jika amil zakat atau lembaga yang berwenang mengumpulkan zakat dapat berperan dengan baik, maka meningkatlah kesejahteraan delapan asnaf yang disebutkan didalam Al-Qur'an, namun sebaliknya jika amil zakat atau lembaga yang berwenang mengumpulkan zakat tidak dapat berperan dengan baik, maka harapan terhadap 
Jauwahir, Heri Kusmanto \& Isnaini, Peran Baitul Mal Langsa dalam Pengelolaan zakat Dan Infaq Untuk

kesejahteraan delapan asnaf puntidak akan mampu diwujudkan. Itulah nilai strategis amil. Dengan katalain, hal yang terpenting dari zakat adalah bagaimana sistem pengelolaannya.

Menurut undang-undang nomor 23 tahun 2011 pengelolaan zakat bertujuan untuk meningkatkan efektivitas dan efisiensi pelayanan dalam pengelolaan zakat, meningkatkan manfaat zaka tuntuk mewujudkan kesejahteraan masyarakat serta penanggulangan kemiskinan. Dalam sistem pengelolaannya lembaga amil zakat menjalankan fungsinya dalam hal perencanaan, pelaksanaan dan pengoordinasian baik dalam hal pengumpulan, pendistribusian dan pendayagunaan zakat.

Zakat dalam pendayagunaannya dapat digunakan untuk usaha produktif dalam rangka penanganan fakir miskindan peningkatan kualitas umat. Selain itu dalam undang-undang juga terdapat pelarangan, yaitu setiap orang tidak dibenarkan untuk bertindak selaku amil zakat dalam hal melakukan pengumpulan, pendistribusian, atau pendaya gunaan zakat tanpa izin pejabat yang berwenang.

Berdasarkan data penelitian Baznas bahwa zakat di Indonesia diperkirakan bisa mencapai 200 Triliun lebih, tetapi baru masuk Badan Amil Zakat Nasional (Baznas) 8,1 Triliun. Artinya masih ada potensi yang besar terhadap zakat untuk mengentaskan kemiskinan, memberdaya SDM, sehingga dapat memajukan ekonomi syariah Indonesia di Dunia (https://www.kompasiana.com/ahmadajib07 /5dad33acc0cfa107c540f323/menggali-

potensi-zakat-untuk-kemaslahatan-umat).

Di Kota Langsa, Baitul Mal terus mengumpulkan dana zakat dengan berbagaicara, sehingga dana yang dikumpulkan terus meningkat dari tahun ketahun, namun manfaatnya belum cukup signifikan dirasakan oleh masyarakat dalam hal meningkatkan kesejahteraan, hal ini dibuktikan dengan angka kemiskinan yang terus meningkat dari tahun ke tahun. Zakat seharusnya dikelola secara produktif dan profesion sehingga zakat dapat mengambil bagian dalam mewujudkan ide-ide Islam untuk mensejahterakan masyarakat. Persoalan yang muncul pada Baitul Mal Kota Langsa ini disebabkan oleh pemahaman masyarakat yang masih minim dalam persoalan zakat juga kurangnya kepercayaan mustahik zakat kepada lembaga amil zakat. Kemudianpada Baitul Mal Kota Langsa tidak memiliki program berbentuk pemberdayaan ekonomi produktif sejak tahun 2016 sampai sekarang padahal pada tahun-tahun sebelumnya program ini masih dijalankan.

Karena sejatinya program pemberdayaan merupakan salah satu cara mendistribusikan zakat dalam kegiatan pengelolaan. Selain itu masyarakat pun masih cenderung membayarkan zakatnya langsung kepada mustahiq, padahal menurut undang-undang hal itu tidak dibenarkan.

Dan berikut adalah Data 3 Tahun terakhir yang telah di kumpulkan oleh Baitul Mal Kota Langsa melalui program yang dijalanakan oleh Pemko Langsa:

Tabel 1: Rekapitulasi Penerimaan \& Penyaluran Zakat Baitul Mal Kota Langsa Tahun 2017 s/d

\begin{tabular}{lllll}
\hline NO & URAIAN & PENERIMAAN & TAHUN & Persentase \\
\hline $\mathbf{1}$ & Terima dari Kas Daerah & $\mathbf{3 . 0 3 7 . 2 3 8 . 4 9 8}$ & $\mathbf{2 0 1 9}$ & $\mathbf{2 6 . 5 5 \%}$ \\
\hline $\mathbf{2}$ & Terima dari Kas Daerah & $\mathbf{2 . 4 0 0 . 0 0 0 . 0 0 0}$ & $\mathbf{2 0 1 8}$ & $5.90 \%$ \\
\hline $\mathbf{3}$ & Terima dari Kas Daerah & $\mathbf{2 . 2 6 5 . 5 2 9 . 0 0 0}$ & $\mathbf{2 0 1 7}$ & $\mathbf{0 . 0 0 \%}$ \\
\hline
\end{tabular}

Sumber: Data Dari Bidang Penerimaan

Dari tabel di atas dapat diketahui dan di lihat bahwa penerimaan Zakat pada tahun 2017 sebesar Rp. 2.265.529.000,- dan penerimaan zakat pada tahun 2018 meningkat sekitar $5.90 \%$ dengan jumlah penerimaan sebesar Rp. 2.400 .000 .000 ,- berikutnya pada tahun 2019 semakin meningkat denga persentase $26.55 \%$ dengan jumlah penerimaan Rp. 3.037.238.498,. Jadi berdasarkan tabel diatas bahwa Penerimaan Zakat yang terkumpul dibagian
Penerimaan Baitul Mal Kota Langsa terus meningkat seiring tahun berjalan.

Penelitian terdahulu yang telah dilakukan misalnya oleh Taufik Nurhidayat Judul Penelitian Pengelolaan Dana Zakat, Infaq Dan Shadaqah UntukPemberdayaan Ekonomi Umat (Studi Pada Lembaga Amil Zakat Taj Quro. Pengelolaan zakat pada masa sekarang ini telah berkembang pesat,baik yang ditangani lembaga swasta maupun pemerintah, tetapi 
masih perlu diberdayakan lagi potensi zakat tersebut selain sebagai menunaikan perintah rukun Islam yang keempat, juga untuk kelangsungan umat. Penelitiannya Nazlah Khairina dengan judul Analisis Pengelolaan Zakat, Infak, Dan Sedekah (ZIS) Untuk Meningkatkan Ekonomi Duafa (Studi Kasus di Lembaga Amil Zakat Nurul Hayat Cabang Medan). Penelitian ini bertujuan untuk menganalisis cara LAZ Nurul Hayat dalam menghimpun dana ZIS dan untuk menganalisis bagaimana cara pendistribusian ZIS oleh Nurul Hayat dalam meningkatkan ekonomduafa, untuk menganalisis bagaimana strategi yang dilakukan LAZ Nurul Hayat dalam meningkatkan ekonomi duafa. Adapun metodologi penelitian ini adalah menggunakan penelitian kualitatif dengan pendekatan deskriptif. Nugraha Hasan, 2017 dengan Judul Pengelolaan Zakat MalT erhadap Peningkatan Kesejahteraan Masyarakat (Studi Kasus Baznaz Kabupaten Sidrap) Menyimpulkan Zakat merupakan instrumen penting dalam pembangunan ekonomi. Dikarenakan potensi zakat yang sangat melimpuh untuk mewujujudkan hal tersebut pemerintah dapat berperan aktif dengan menyempurnakan peraturan perundang-undangan yang ada, serta masyarakat harus sadarakan kewajibannya sebagai muslim untuk menunaikan zakatnya dan mempercayakan dana zakatnya dikelola melalui lembaga pengelolazaka tyang dibentuk pemerintah, olehkarena itu lembaga pengelola zakat wajib bersifat transparan, professional, dana kuntabel demi mewujudkan masyarakat sejahtera.

NELI Pada Tahun 2017 yang berjudul Manajeman Zakat DiLembaga Amil Zakat Dompet Ummat Kabupaten Sambas Penelitian ini bertujuan untuk mengetahui: (1) pengelolaan zakat di Lembaga Amil Zakat Dompet Ummat Kabupaten Sambas. (2) implikasi Lembaga Amil Zakat Dompet Ummat Sambas dalam pembangunan masyarakat sambas secara menyeluruh. Hasil penelitian menunjukan: (1) Manajmen pengelolaan pengumpulan dan pendistribusian zakat di Lembaga Amil Zakat Dompet Ummat Kabupaten Sambas secara perencanaan, pengawasan, pelaksanaan, dan pengorganisasian memang hampir sudah berjalan dengan baik, hanya job descripsidi setiap divisinya belum tersusun. tetapi dalam pendistribusian dan manajeman pengelolaan dana nya belum menerapkan pengelolaan yang sesuai kaidah dan aturan hukum syari'ah, (2) Implikasi pendayagunaan dan pendistribusian zakat di Lembaga Amil Zakat Dompet Ummat Kabupaten Sambas belum meningkatkan kesejahteraan masyarakat secara keseluruhan, karena didalam pembagian proporsional zakat belum sesuaisyar'at.

Pada penelitiannya Wara Komaria. 2010. Yang berjudul pengelolaan dana zakat, infaq, dan shadaqah (ZIS) pada Lembaga Kantor Zakat LPUQ dan Badan Amil Zakat (BAZ) memilik hasil Kinerja pengelolaan dana ZIS pada BAZ Kabupaten Jombang masih kurang optimal. Terlihat dari segi pendistribusian dana ZIS yang tidak sebanding dengan jumlah dana ZIS yang terkumpul dan Kinerja pengelolaan dana ZIS pada Kantor Zakat LP-UQ sangat amanah dan profesional. Banyak donatur yang mempercayai kinerja pengelolaan Kantor Zakat LP-UQ. Dana ZIS yang terkumpul segera di distribusikan kepada yang membutuhkan. Sedangkan dana zakat yang terdistribusi tidak mempengaruhi pendapatan mustahiq. Karena dana ZIS yang disalurkan dapat dikatakan masih jauh dari jumlah dana yang diharapkan bisa membantu terpenuhinya kebutuhan mustahiq. Dan untuktingkat kepuasan Dari 20 responden muzakki menunjukkan sebagian besar responden yaitu sebanyak 46\% menyatakan kinerja pengelolaan ZIS pada BAZ Kabupaten Jombang kurang memuaskan. Dikarenakan kinerja pengelolaan dana ZIS yang kurang optimal. Sedangkan pada Kantor Zakat LP-UQ Kabupaten Jombang 41\% menyatakan kinerja pengelolaan ZIS Kantor Zakat LP-UQ pada Kabupaten Jombang sangat memuaskan. Dikarenakan kinerja pengelolaan dana ZIS pada Kantor Zakat LP-UQ sangat amanah dan profesional.

Melihat penelitian yang terdahulu di atas, maka tujuan penulsan ini adalah untuk mengetahui peran dan mengkaji kendala apa saja yang dihadapi Baitul Mal Langsa dalam memberdayakan Masyarakat.

\section{METODE PENELITIAN}

Jenis penelitian ini adalah Field Research atau penelitian lapangan yang bersifat studi kasus, yaitu penelitian yang dilakukan secara intensif terinci dan mendalam terhadap suatu organisasi, lembaga atau gejala tertentu (Arikunto, 2002) dengan cara mengumpulkan keterangan yang diperlukan dengan jalan 
berkunjung kerumah atauketempat orangorang atau badan-badan yang akan diminta keterangannya (Margono, 2004).

Pendekatan yang dilakukan dalam penelitian ini bersifatkualitatif yaitu penelitian yang perlu dilakukan seusai masalah diteliti secara kualitatif, tetapi belum terungkapkan penyelesaiannya (Subana, \& Sudrajat, 2001). Penelitian kualitatif sifatnya deskriptif, karena data yang dianalisis tidak untuk menerima atau menolak hipotesis (jika ada), melainkan hasil analisis itu berupa deskriptif dari gejala-gejala yang diamati, yang tidak selalu harus berbentuk angka-angka atau koefisien antarvariabel. Deskriptif adalah apa yang dilakukan dan dikatakan oleh para pelaku, proses yang sedang berlangsung dan berbagai aktivitas lain dalam konteks alamiah, maka penelitimesti mendeskripsikan atau menggambarkan segala sesuatu yang diindrainya secara lengkap, rinci, dan mendalam. Untuk itulah si peneliti wajib membuat catatan lapangan dan catatan wawancara yang rinci, lengkap dan apa adanya.

Waktu yang digunakan peneliti untuk penelitian ini dilaksanakan sejak tanggal dikeluarkannya ijin penelitian dalam kurun waktu kurang lebih 2 (dua) bulan, 1 bulan pengumpulan data dan 1 bulan pengolahan data yang meliputi penyajian dalam bentuk skripsi dan proses bimbingan berlangsung.

Tempat pelaksanaan penelitian ini adalah di Baitul Mal Kota Langsa, Jln. A. Yani No. 8, Cakra Donya Langsa Kota, Kota Langsa. Penulis memilih untuk melakukan penelitian di Baitul Mal Kota Langsa adalah dikarenakan faktor tempat penulis bekerja saat ini, jadi dengan ditetapkannya lokasi penelitian ini sehingga mempermudah penulis dalam melakukan penelitian. Dan dapat mempermudah penulis dalam menyusun atau mengumpulkan Data yang penulis butuhkan untuk menyelesaikan Penelitian ini.

Adapun sumber data yang digunakan dalam penelitian adalah Data primer adalah data yang diperoleh peneliti secara langsung, dalam hal ini data yang diperoleh dari hasil wawancara ataupun observasi langsung pada objek penelitian. Data sekunder adalah data yang diperoleh peneliti dari sumber yang sudah ada, seperti gambaran umum perusahaan, struktur organisasi, dan sebagainya.(Sunyoto, 2013)

Responden adalah orang yang diminta untuk memberikan keterangan tentang suatu fakta atau pendapat. Sebagaimana dijelaskan oleh Arikunto (2006) subjek penelitian adalah subjek yang ditujuuntuk diteliti oleh peneliti. Jadi, subjek penelitian itu merupakan sumber informasi yang digali untuk mengungkap faktafakta di lapangan.Penentuan subjek penelitian atau sampel dalam penelitian kualitatif berbeda dengan penelitian kuantitatif.

Penulis menentukan responden berdasarkan data tabel yang sudah penulis sediakan selama 3 (tiga) tahun terakhir.Responden pada penelitian ini yaitu sebanyak 7 (Tujuh) responden yang merupaka Kepala Baitul Mal, Sekretaris dan Staff atau pengurus yang merupakan kunci berlangsungnya kegiatan Penyaluran Zakat dan Infaq. Berikut adalah tabel yang saya rangkum.

Tabel 3, Responden Berdasarkan Data Tabel Selama 3 (Tiga) Tahun Terakhir

\begin{tabular}{lll}
\hline No & Jabatan & Jumlah \\
\hline $\mathbf{1}$ & Ka. Baitul Mal Kota Langsa & 1 Orang \\
\hline $\mathbf{2}$ & Ka. Sekretariat Baitul Mal Kota Langsa & $\mathbf{1}$ Orang \\
\hline 3 & Staff atau Pengurus Baitul Mal Kota Langsa & 5 Orang \\
\hline
\end{tabular}

Berdasarkan Tabel 3 dapat diketahui bahwa responden penelitian yang penulis sediakan adalah 1(satu) orang Ka. Baitul Mal Kota Langsa, 1 (satu) orang Ka. Sekretariat Baitul Mal Kota Langsa, dan 5 (lima) orang Staff atau Pengurus yang menjadi responden.

Menurut Subagyo, observasi adalah pengamatan yang dilakukan secara sengaja, sistematis mengenai fenomena sosial dengan gejala-gejala psikologis untuk kemudian dilakukan pencatatan (Subagio, 2004).

Dokumentasi menurut Sugiyono (2015) adalah suatu cara yang digunakan untuk memperoleh data dan informasi dalam bentuk buku, arsip, dokumen, tulisan angka dan gambar yang berupa laporan serta keterangan yang dapat mendukung penelitian. Dokumentasi digunakan untuk mengumpulkan data kemudian ditelaah. 
Wawancara adalah suatu percakapan dengan maksud tertentu yang dilakukan kedua belah pihak, yaitu pewawancara (interviewer)yang mengajukan pertanyaan dan yang mewawancarai (interviewee) yang memberikan jawaban atas pertanyaan itu (Subagio, 2004).

Definisi Konseptual yaitu suatu definisi yang masih berupa konsep dan maknanya masih sangat abstrak walaupun secara intuitif masih bisa dipahami maksudnya (Saifuddin, 2007). Definisi konseptual dalam penelitian ini adalah Baitul Mal Kota Langsa yaitu suatu lembaga yang diadakan dalam pemerintahan Islam untuk mengurus masalah keuangan nagara. Atau, suatu lembaga keuangan negara yang bertugas menerima, menyimpan, dan mendistribusikan uang negara sesuai dengan syariat Islam. Tujuan dibentuknya baitul mal dalam suatu negara mempunyai peranan yang cukup besar sebagai sarana tercapainya tujuan negara serta pemerataan hak dan kesejahteraan kaum muslimin. Baitul mal lebih mengarah pada usaha-usaha pengumpulan dan penyaluran dana yang nonprofit, seperti zakat, infak dan sedekah.

Definisi Operasional, menurut Azwar (2007) adalah suatu definisi yang memiliki arti tunggal dan diterima secara objektif bilamana indikatornya tidak tampak. Adapun Definisi Operasional yang penulis maksud ialah Zakat. Zakat merupakan ibadah yang memiliki dimensi sosial yang tinggi dan berfungsi untuk mewujudkan solidaritas sosial, mengentaskan kemiskinan, pembiayaan pendidikan, pertolongan terhadap orang-orang yang menderita dan kegiatan sosial lainnya. Zakat akan berfungsi sebagai sumber perekonomian rakyat jika dikelola dengan baik, profesional, dan bertanggung jawab. Ada beberapa cara untuk dapat mengelola zakat dengan baik.

Dalam an alisis data diperlukan beberapa tahapan,sepertiyang diungkapkan Bungin dalam bukunya Analisis Data Penelitian Kualitatif, yakni: Data collection, atau koleksi dat aialah pengumpulan data dengan analisis data, yang mana data tersebut diperoleh selama melakukan pengumpulan data tanpa proses pemilahan. Data reduction yaitu pengolahan data yang mencakup kegiatan mengikhtiarkan hasil pengumpulan data selengkap mungkin, dan memilah-milahnya ke dalam satuan konsep tertentu, kategori tertentu atau tema tertentu. Data display atau penyajian data ialah data yang dari kencah penelitian dipaparkan secara ilmiah oleh peneliti dengan tidak menutupi kekurangan.

\section{HASIL DAN PEMBAHASAN \\ Peran Baitul Mal Kota Langsa Dalam Pengelolaan Zakat dan Infaq Untuk Pemberdayaan Masyarakat Kota Langsa.}

Baitul Mal memiliki peran untuk mengurus, mengelola, mengumpulkan, menyalurkan, serta mendayagunakan zakat. pengumpulan zakat dilakukan dengan cara menerima atau mengambil dari orang yang mengeluarkan zakat (muzakki) berdasarkan pemberitahuan muzakki.

Diantara program pemberdayaan Baitul Mal Kota Langsa yang telah berjalan :

1. Penyaluran zakat konsumtif untuk para mustahiq yang rutin dilaksanakan pada setiap tahun.

2. Membangun/mengrehap rumah-rumah, bagi para mustahiq yang masih tinggal di tempat-tempat yang tidk layak huni.

3. Mengirim para pelajar potensial dari keluarga tidak mampu untuk mengikuti pendidikan tahfi zul Qur'an di dayah AlAtiyah Li Tahfi zhil Qur'an Saree dan MUQ Pagar Air Lam Baroe Banda Aceh melalui program beasiswa penuh.

4. Memberikan Bantuan Biaya Pengajian bagi para Muallaf yang memiliki komitmen memperdayakan keislamannya dengan belajar didayah/pesantren

5. Bantuan Rehab Mesjid dan Mushalla yang sedang dalam pengrehapan atau pembangunan

6. Pengajian rutin Muallaf se-Kota Langsa

7. Memberikan bantuan berupa sembako kepada anak asuh yang berada di panti Asuhan se-Kota Langsa.

8. Bantuan Resposif tanggap darurat musibah dan bencana alam

9. Bantuan fakir Uzur setiap Bulannya yang dibagikan enam bulan se kali dalam setahun.

10. Pembangunan komlek pembinaan Muallaf di jln. Medan Banda Aceh, Dusun Malahayati Gampong Seriget

11. Penyaluran senif Fi Sabilillah sinergisitas dengan proram safari Magrib walikota Langsa.

12. Bantuan Untuk penjaga pasien rujukan (Brosur Baitul Mal Kota Langsa). 


\section{Keberadaan Baitul Mal Kota Langsa}

Sebagaimana Baitul Mal merupakan suatu lembaga yang mempunyai tugas khusus mengenai harta ummat Islam berupa pendapatan dan pengeluarannya. Salah satunya Baitul Mal menghimpun dana dari masyarakat. Baitul Mal melakukan beberapa program untuk mencapainya, yaitu potong langsung yang secara potong langsung yang dilakukan oleh bendahara pada setiap instansi kepada pihak Baitul Mal, Setor Bank berarti muzakki mentransfer ke rekening Baitul Mal, serta adanya program di jemput atau mengantar ke Baitul Mal. Kemudian Baitul Mal juga mengkategorikan untuk instansi dalam menghimpun dana seperti instansi pemerintah, instansi sekolah dan perorangan. Kemudian pihak Baitul Mal menghimpun dana dari masyarakat den-gan cara bersilaturahmi dengan muzakki yang sudah sampai haulnya untuk membayar zakat (Hasil Wawancara dengan Bapak Surianto, Karyawan Baitul Mal Kota Langsa).

Setelah Baitul Mal menghimpun dana dari masyarakat, kemudian dana ini akan dikelola oleh Baitul Mal dan akan disalurkan kepada pihak atau masyarakat yang membutuhkan, yaitu fakir, miskin, fi sabilillah, ibnu sabil, garim, muallaf, amil sebe-sar Rp. 150.000. Jika dana infak maka akan disalurkan untuk dana bantuan sekolah (beasiswa), pembangunanpembangunan dayah atau rehab rumah dan lain-lain (Hasil Wawancara dengan Ibu Nurhamida, Karyawan Baitul Mal Kota Langsa).

Kemudian dalam rangka meningkatkan kesejahteraan masyarakat, maka Baitul Mal mengupayakan bantuan modal bertujuan untuk meningkatkan kesejahteraan masyarakat miskin. Tekhniknya khusus infak yaitu: Menerima proposal (permohonan), mendata proposal, survey, analisis kelayakan, realisasi bantuan, kemudian mem-buat laporan (Hasil Wawancara dengan Bapak Safwan, Karyawan Baitul Mal Kota Langsa).

\section{Pengelolaan Zakat}

Secara umum pengelolaan Baitul Mal diupayakan dapat menggunakan fungsi-fungsi manajemen modern yang meliputi perencanaan, pelaksanaan, pengorganisasian dan pengarahan serta pengawasan. Perencanaan meliputi merumuskan rancang bangun organisasi, perencanaan program kerja yang terdiri dari penghimpunan, pengelolaan dan pendayagunaan. Pengorganisasian meliputi koordinasi, tugas dan wewenang, penyusunan personalia, perencanaan personalia dan recruiting. Pelaksanaan dan pengarahan terdiri dari; pemberian motivasi, komunikasi, model kepemimpinan, dan pemberian reward dan sangsi, sedangkan pengawasan meliputi tujuan pengawasan, tipe pengawasan, tahap pengawasan.

Selanjutnya penulis berhasil mengindentifikasi beberapa permasalahan terkait dengan eksistensi Baitul Mal dalam meningkatkan kesejahteraan. Sangat perlu untuk di cari penjelasannya, guna melihat apakah Baitul Mal telah eksis di tengah-tengah masyarakat miskin untuk mensejahertakan mereka.

Baitul Mal di Kota Langsa telah melaksankan tujuannya, di antara Usaha yang sudah dilakukan Baitul Mal yaitu seperti bantuan alat kesehatan, sunatan masal, bantuan anak yatim, pembangunan rumah fakir miskin (Hasil Wawancara dengan ibu Maya, Masyarakat Kota Langsa). Petugas Baitul Mal menijau kelapangan langsung layak gak di bantu, terus kalau layak petugas Baitul Mal memberikan bantuan kepada yang membutuhkan (Hasil Wawancara dengan Ibu Supriati, Masyarakat Kota Langsa). Memberikan bantuan dana (uang), bantuan Fi Sik seperti contohnya bangun, rehap rumah, kalau dulu ada modal usaha sekarang modal usaha tidak ada lagi (Hasil Wawancara dengan Ibu Sari, Masyarakat Kota Langsa). Salah satunya, turun langsung mendata, mengobservasi masyarakat miskinya, sudah memberikan bantuan yang layak sudah sangat berjalanlah kerja Baitul Malnya (Hasil Wawancara dengan Ibu Intan, Masyarakat Kota Langsa).

Dengan pendataan langsung jadi tau siapa yang berhak menerima bantuan, dan Baitul Mal selalu memberikan informasi dan motivasi kepada masyarakat, seperti memberikan dakwah atau ceramah kepada masyarakat dalam bentuk sosialisasi. Baitul Mal mengobservasi masyarakat miskinya, sudah memberikan bantuan yang layak. Memberikan bantuan dana (uang), bantuan fisik seprti contohnya bangun, rehap rumah, ini terlihat sudah bahwa Baitul Mal berperan dalam mensejahterakan masyarakat. Peran Baitul Mal dalam mensejahterakan masyarakat miskin sudah sesuai, berikut penjelasannya: 
Iya, sedikit banyaknya sudah sesuai. Karena banyak dari warga kampong sini sudah sejahtera dan hidup dengan lebih layak (Hasil Wawancara dengan Ibu Maya, Masyarakat Kota Langsa). Sudah sesuai, sudah ada pembangunan rumah dhuafa, pembagian dana ke anak yatim , pokoknya yang 8 senif yang ada di dalam Al Quran (Hasil Wawancara dengan Ibu Supriati, Masyarakat Kota Langsa). Selama itu terjalankan dengan adil dan makmur maka masyarakat sejahtera dan senang, bahagia dalam me-nerimanya dilihat dari sekeliling insya Allah sudah sesuai (Hasil Wawancara dengan Ibu Nindy, Masyarakat Kota Langsa).

Berdasarkan hasil wawancara, sedikit banyaknya sudah sesuai peran Baitul Mal mensejahterakan masyarakat melalui bantuan, karena banyak dari warga kampong sini sudah sejahtera dan hidup dengan lebih layak (penjelasan ibu maya) dan ada pembangunan rumah dhuafa, pembagian dana anak yatim. Terlaksanakan dengan adil dan makmur sehingga masyarakat sejahtera dan senang, bahagia dalam meneri-manya dilihat dari sekeliling insya Allah sudah sesuai.

Masih sedikit terlaksana peran Baitul Mal, karena penyaluran zakat belum tepat sasaran dan angka kemiskinan belum berkurang (Hasil Wawancara dengan Ibu Sari, Masyarakat Kota Langsa). Yang saya tau ya belum sesuailah, mereka sudah tau siapa yang harus diprioritaskan terlebih dahulu namun mungkin dana bantuan terbatas sehingga yang harus diprioritaskan pun masih terabaikan (Hasil Wawancara dengan Ibu Intan, Masyarakat Kota Langsa).

Dengan diberikan bantuan oleh Baitul Mal masyarakat sudah sejahtera setidaknya, berikut hasil wawancara dengan Ibu Maya dan Ibu Nindy:

Iya sudah sejahtera. Karena dapat dengan Bantuan Baitul Mal masyarakat itu sendiri bisa hidup dengan layak dan dengan bantuan Baitul Mal tentang memberikan alat-alat kesehatan seperti kursi roda atau alat bantu berjalan (tongkat) bagi masyarakat tidak mampu yang tidak bisa berjalan (cacat) dll (Hasil Wawancara dengan Ibu Maya, Masyarakat Kota Langsa). Menurut saya. Sebahagian sudah sejahtera dan sebahagian belum sejahtera dikarenakan tidak dapat di manfaatkan dana itu secara jenjang lama (Hasil Wawancara dengan Ibu Supriati, Masyarakat Kota Langsa). Kalau dikatakan manusia tidak akan ada kata sejahtera karena sifat manuisa tidak pernah merasakan puas selalu kurang, tapi setidaknya untuk menjalankan hidupnya yang se-mestinya sudah dikategorikan lancar / bagus (Hasil Wawancara dengan Ibu Nindy, Masyarakat Kota Langsa).

Berdasarkan hasil wawancara bahwa sebahagian sudah sejahtera dan sebaha-gian belum sejahtera dikarenakan tidak dapat dimanfaatkan dana itu secara jenjang lama. Kalau dikatakan manusia tidak akan ada kata sejahtera karena sifat manui-sa tidak pernah merasakan puas selalu kurang, tapi setidaknya untuk menjalankan hidupnya yang semestinya sudah dikategorikan lancar/bagus.

Mungkin hanya beberapa orang, karena kita kan tidak tahu ekonomi orang kayak mana, tapi dengan adanya bantuan sudah sangat membantulah (Hasil Wawancara dengan Ibu Mia, Masyarakat Kota Langsa). Belum tentu, tergantung bentuk bantuan dan bagaimana bantuan itu di manfaatkan, misalnya bentuk bantuan sebesar Rp 100.000,- udah jelas tidak bisa mensejahterkan sudah habis 1 hari saja bantuan lebih besar akan sejahtera (Hasil Wawancara dengan Ibu Sari, Masyarakat Kota Langsa). Untuk mereka yang sangat membutuhkan pastinya sudah sangat membantu, dan su-dah sangat mensejahterakan masyarakat dengan cara member bantuan (Hasil Waw-ancara dengan Ibu Intan, Masyarakat Kota Langsa).

Pada akhirnya. Baitul Mal Kota Langsa masih belum mampu meningkatkan kesejahteraan masyarakat di Kota Langsa. jika dianalisis ada beberapa persoalan yang menjadi penyebabnya :

Pertama, adalah pelaksanaan sosialisasi pentingnya Baitul Mal dengan pendeka-tan teknologi informasi, hal ini sangat penting menggingat zaman terus berkembang. Dengan menggunakan teknologi informasi, tujuan Baitul Mal untuk mengajak masyarakat untuk berzakat melalui Baitul Mal akan lebih efektif. Untuk kedepan pengurus Baitul Mal perlu membuat sebuah trobosan terkait dengan proses sosialisasi dengan menggunakan teknologi informasi untuk memperoleh kepercayaan masyarakat.

Kedua, Baitul Mal belum banyak mengunakan komunikasi informasi menghimpun dana zakat melaui instansi/ lembaga pemerintah ataupun swasta. Padahal banyak potensi zakat yang terdapat di berbagai instansi/ lembaga di Kota Langsa. Dengan 
demikian, Baitul Mal tidak hanya menyantumkan dana zakat dari masyarakat. Namun diharapkan, hal ini akan meningkatkan jumlah penerima zakat sehingga mampu meningkatkan kualitas mustahik di Kota Langsa.

\section{Optimalisasi Penyaluran Dana Baitul Mal Kota Langsa}

Berdasarkan keterangan dari beberapa narasumber menyembutkan bahwa ada 3 program yang dilakukan dalam menghimpun dana yaitu: Pertama, potong Langsung, Kedua, stor Bank, Ketiga, di jemput/mengantar ke Bantul Mal, Kemudian juga ditambahkan bahwa ada 3 kategori sumber dana Baitul Mal yaitu Pertama, Instansi pemerintah, Kedua, Instansi sekolah, Ketiga, perorangan (Wawancara dengan Safwan kamal Kasubbag Pendistribusian).

Untuk instansi pemerintah dan sekolah dikum-pulkan melalui opejet (unit pengumpul zakat), sedangkan untuk perorangan bisa langsung ke Bank atau datang ke Baitul Mal dan bisa juga dengan mekanisme jemput zakat. Contoh, showroom meminta ke tim Baitul Mal supaya zakatnya di jemput ke tempatnya. Sebagaimana Baitul Mal merupakan suatu lembaga yang mempunyai tugas khu-sus mengenai harta ummat Islam berupa pendapatan dan pengeluarannya. Salah satunya Baitul Mal menghimpun dana dari masyarakat (Wawancara dengan Syahrun Ka. Bagian Pendistribusian dan Pendayagunaan Zakat).

Baitul Mal melakukan beberapa program untuk mencapainya, yaitu potong langsung yang secara potong langsung yang dilakukan oleh bendahara pada setiap instansi kepada pihak Baitul Mal, Setor Bank berarti muzakki mentransfer ke rekening Baitul Mal, serta adanya program di jemput atau mengantar ke Baitul Mal. Kemudian Baitul Mal juga mengkategorikan untuk instansi dalam menghimpun dana seperti instansi pemerintah, instansi sekolah dan perorangan. Kemudian pihak Baitul Mal menghimpun dana dari masyarakat dengan cara bersilaturahmi dengan muzakki yang sudah sampai haulnya untuk membayar zakat.

Setelah Baitul Mal menghimpun dana dari masyarakat, kemudian dana ini akan dikelola oleh Baitul Mal dan akan disalurkan kepada pihak atau masyarakat yang membutuhkan, yaitu Fakir, Miskin, Fi Sabilillah, Ibnu Sabil,
Garim, Muallaf, amil sebesar Rp. 150.000. Jika dana infak maka akan disalurkan untuk dana bantuan sekolah (beasiswa), pembangunanpembangunan dayah atau rehab rumah dan lain-lain.

Kemudian dalam rangka meningkatkan kesejahteraan masyarakat, maka Baitul Mal mengupayakan bantuan modal bertujuan untuk meningkatkan kesejahteraan masyarakat miskin. Tekhniknya khusus infak yaitu: Menerima proposal (permohonan), mendata proposal, survey, analisis kelayakan, realisasi bantuan, kemudian mem-buat laporan.

Berkaitan dengan tujuan penyaluran dana Baitul Mal dalam jangka pendek yaitu menyalurkan zakat fakir dan miskin setiap setahun sekali pada bulan ramadhan untuk 66 kampung Kota Langsa, memberikan bantuan ke panti asuhan setahun sekali, contohnya lagi Baitu Mal memberikan bantuan kepada yang membutuhkan setiap bulan ramadhan dan pada saat menjelang hari raya Idul Fitri bantuan ini diberikan sebesar Rp.150.000 x 2 dapat total Rp.300.000. Selanjutnya infak jangka panjang yaitu bantuan modal usaha terus/ menerus, yang jompo serta hafidz AlQur'an setiap bulan diberi bantuan sebesar Rp.50.000 perbulan.

Selanjutnya juga terdapat program zakat tepat sasaran yang ditujukan untuk meningkatkan kesejahteraan masyarakat miskin, yaitu zakat dalam bentuk uang tunai dengan mensosialisasi kampung-kampung untuk mencari atau mendata orang yang rumah tidak layak dan penghasilan kurang.

Berdasarkan hasil wawancara di atas dapat disimpulkan bahwa program kerja Baitul Mal belum optimalnya terlaksana. Hal ini dapat dilihat melalui program- program kerja yang tidak terlaksana ataupun program- program kerja yang belum maksimal pelaksanaannya.

\section{Pemberdayaan}

Pemberdayaan menurut Winarni (1998) dalam Purnomo (2018) merupakan konsep pemberdayaan masyarakat, dimana inti dari pemberdayaan adalah meliputi tiga hal yaitu pengembangan (enabling), memperkuat potensi atau daya (empowering) dan terciptanya kemandirian.pemberdayaan merupakan keniscayaan dalam pembangunan, terutama pembangunan dalam rangka pengentasan kemiskinan. Pemberdayaan 
berinti pada masayarakat merupakan tuntutan utama pembangunan, ini terkait dengan teori sumber daya manusia yang memandang mutu penduduk sebagai kunci utama pembangunan. Banyaknya penduduk bukan beban suatu bangsa, bila mutunya tinggi, untuk itu pembangunan hakekat manusiawi hendaknya menjadi arah pembangunan dan perbaikan mutu sumber daya manusia akan menumbuhkan inisiatif dan kewiraswastaan (Anwar, 2007 dalam Purnomo, 2018; (Jamaluddin et al., 2019; Santifa et al., 2019; Aruan \& Rawaty, 2020; Aini, \& Wulandari, 2021; Mustafa, 2021; Berutu, et al., 2019; Nurmiah et al., 2019)

Dengan demikian berdasarkan konsep pemberdayaan tersebut zakat. Infak/sedekah dapat di dayagunakan dan di kelola agar memiliki manfaat atau daya guna sesuai dengan tujuan zakat itu sendiri (Nafiah, 2015). menurut Sjechul Hadi Permono dalam Nafiah (2015) pendayagunaan zakat adalah segala sesuatu yang berkaitan dengan usaha pemerintah dalam memanfaatkan hasil pengumpulan zakat untuk didistribusikan kepada mustahik (sasaran penerima zakat) dengan berpedoman syariah, tepat guna, serta pemanfaatan yang efektif melalui pola pendistribusian yang bersifat produktif dan memiliki manfaat seusai dengan tujuan ekonomis zakat. Pendayagunan zakat dapat menurut Nafiah (2015)dapat menggunakan indikator sebagai berikut: a) Kemampuan amil dalam mengelola serta menyalurkan kepada mustahiq. b) Pemanfaatan pada sektor produktif. c) Objek Zakat.

\section{Kendala Baitul Mal Kota Langsa Dalam Memberdayakan Masyarakat Kendala Dalam \\ Optimalisasi \\ Penghimpunan Dana Baitul Mal. Besaran} dana ummat yang masuk atau yang terkumpul ke Baitul Mal sangat tergantung dari antusiasme masyarakat untuk mempercayakan dana zakat mereka ke lembaga tersebut. Disinilah permasalahan mulai muncul ketika masyarakat belum banyak mengetahui mengenai program-program Baitul Mal Kota Langsa. Padahal Baitul Mal sendiri sebetulnya sudah melakukan beberapa metode untuk mendekatkan lembaga tersebut kepada masyarakat misalnya : Bersosialisasi melalui pendekatan ceramah, Pemasangan Baliho, Membagikan Browsur, Media (FB Baitul Mal).
Namun metode tersebut memiliki beberapa permasalahan-Permasalahan Sosialisasi di Baitul Mal Kota Langsa, yaitu :

Kurangnya Baliho di setiap sudut Kota Langsa jadi masyarakat kurang mengetahuinya, seharusnya di setiap sudut Kota Langsa harus di pasang Baliho tentang wajib berzakat oleh Baitul Mal Kota Langsa.

1. Brosur yang di cetak oleh Baitul Mal sedikit, seharusnya Baitul Mal harus mencetak Brosur dengan sesuai kapasitas yang ada di Kota Langsa, terus setiap Muzakki membayar ke Baitul Mal wajib memberikan Browsur kepada yang membayar zakat, infak, sedekah jangan yang kenal saja yang di kasih tetapi semua yang membayar zakat di kasih

2. Kurangnya Tim Baitul Mal untuk bersosialisasi kepada masyarakat Kota Langsa.

3. Kurangnya dana pemerintahan jadi tim Baitul Mal bersosialisasi Cuma berapa bulan sekali.

Dalam proses penghimpunan Baitul Mal memberlakukan beberapa metode yaitu : Potong Langsung (Melalui Bendahara), Stor ke Bank, Di jemput/ mengantar ke Baitul Mal. Namun ternyata hal tersebut tidak meningkatkan secara singnifi kan jumlah dana ummat yang berhasil di himpun oleh Baitul Mal. Selain karena metode sosial-isasi yang belum berhasil melakukan pendekatan secara langsung kepada masyarakat ternyata Baitul Mal juga gagal dalam memahami kondisi keuangan masyarakat yang dianggap berpotensi menjadi muzakki. Kondisi muzakki di Kota Langsa tidak semuanya ideal. namun ada juga muzakki yang memiliki permasalahanpermasalahan yang menyebabkan mereka tidak menyalurkan zakat mereka ke Baitul Mal.

Banyak orang yang mempunyai argument masing-masing, Ada berpendapat zakat profesi gak wajib, Ada yang terjerat kredit, Pengusaha banyak menyalurkan zakarnya sendiri. Dengan demikian mereka lebih memilih untuk menunggu sehingga permasalahan mereka selesai dan mereka akan membayar zakat tetapi tidak melalui Baitul Mal. Hal ini lah yang seharusnya mampu di indentifi kasi oleh pihak Baitul Mal dalam proses penghimpunan dana dari muzakki.

Masalah lain yang muncul dalam penghimpunan dana di Baitul Mal yaitu : Seharusnya Baitul Mal harus mampu 
menyalurkan kepada masyarakat bahwa kepada Baitul Mal lah yang cocok dan pas untuk menyalurkan zakatnya melalui Baitul Mal Kota Langsa. karena saat ini Baitul Mal belum tegas dan belum menyakinkan kepada masyarakat Kota Langsa. jadi masyarakat pun banyak argument masing-masing dan berpendapat zakat profesi gak wajib dan pengusahapengusaha banyak menyalur-kan zakatnya sendiri sebenarnya tempat Baitul Mal lah yang baik untuk menyalurkan zakat karena Baitul Mal mempunyai data-data dan kriteria masyarakat Kota Langsa yang berhak menerima bantuan tersebut. Seharusnya Baitul Mal mampu membangun kesadaran dari masyarakat akan pentingnya membayar zakat sehingga di kemudian hari Baitul Mal mampu menjadi lembaga yang bisa mensejahterakan masyarakat miskin.

\section{Kendala Dalam Optimalisasi}

Penyaluran Dana Baitul Mal. Setelah dana ummat terkumpul, Baitul Mal Kota Langsa bertugas mendistri-busikannya kepada masyarakat yang membutuhkan seperti : Fakir, Miskin, Janda kalau di dalam Al Quran telah di jelaskan bahwa yang harus di bantu 7 senif seperti Fakir, Miskin, Ibnu Sabil, orang yang berhutang (Gharim), Amil, Fi Sabilillah. Namun ternyata timbulpermasalahan terhadap tujuan distribusi.

Terkait dengan penyaluran, dalam Mekanisme penyaluran dana Baitul Mal Kota Langsa terdapat keterlibatkan antara Geuchik dan Imam dalam mendata. Baitul Mal sudah bagus tetapi pendataan yang masih kurang karena masih banyak masyarakat yang berhak menerima bantuan tidak dapat bantuan, seharusnya Baitul Mal Kota Langsa harus di validasi oleh Baitul Mal agar penerima tepat sasaran.

Kriteria masyarakat miskin menurut Baitul Mal belum ada kriteria masyarakat miskin yang khusus mereka cuma melihat ke lokasi kalau layak di bantu, seharusnya Baitul Mal Kota Langsa harus mempunyai standar khusus Kriteria-Kriteria masyarakat miskin di kota Langsa. Oleh karena itu penulis menyarankan supaya Baitul Mal melakukan sosialisasi - sosialisasi untuk membangun kesadaran masyarakat tentang pentingnya Baitul Mal agar terjadi peningkatan pengumpulan dana ummat sehingga jumlah dana yang disalurkan semakin besar dan dapat menjangkau masyarakat yang lebih luas.

\section{SIMPULAN}

Baitul Mal memiliki peran untuk mengurus, mengelola, mengumpulkan, menyalurkan, serta mendayagunakan zakat. pengumpulan zakat dilakukan dengan cara menerima atau mengambil dari orang yang mengeluarkan zakat (muzakki) berdasarkan pemberitahuan muzakki. Optimalisasi penyaluran dana Baitul Mal di Kota Langsa bahwa secara umum pengelolaan Baitul Mal Kota Langsa belum efektif dalam meningkatkan masyarakat miskin, dikarenakan Baitul Mal memperoleh bantuan sedikit sebab muzakki masih kurang percaya untuk membayar zakat ke Baitul Mal, ini yang membuat Baitul Mal belum optimal dalam menyalurkan dana ke masyarakat miskin. Eksistensi Baitul Mal dalam meningkatkan kesejahteraan bahwa Baitul Mal belum bisa mensejahterakan masyarakat miskin dikarenakan dana yang terkumpul sedikit, bantuan yang diberikan Baitul Mal masih kurang, zakat yang disalurkan belum tepat sasaran dan Baitul Mal membagikan ke masyarakat miskin pun belum tercapai tujannya untuk mensejahterakan masyarakat miskin

\section{DAFTAR PUSTAKA}

Aini, P., \& Wulandari, S. (2021). Tahapan Pemberdayaan Berbasis Aset Komunitas pada Desa Wisata Pentingsari Yogyakarta. Journal of Education, Humaniora and Social Sciences (JEHSS), 4(1), 37-49. doi:https://doi.org/10.34007/jehss.v4i1.572

Arikunto, S., (2002), Prosedur Penelitian Suatu Pendekatan Praktek, Jakarta: Rineka Cipta.

Aruan, R., \& Rawaty, N. (2020). Internalisasi Pemberdayaan Masyarakat dalam Meningkatkan Kualitas Permukiman Kumuh di Kota Madya Pematang Siantar. Journal of Education, Humaniora and Social Sciences (JEHSS), 3(2), 761-768. doi:https://doi.org/10.34007/jehss.v3i2.365

Berutu, B., Nasution, M., \& Kadir, A. (2019). Peran Badan Usaha Milik Desa (BUMDes) Dalam Pemberdayaan Masyarakat Desa Mungkur Kecamatan Siempat Rube Kabupaten Pakpak Bharat. Strukturasi: Jurnal Ilmiah Magister Administrasi Publik, 1(1), 1-10

http://ejournal.ipdn.ac.id/JAPD/article/download/ $738 / 461$

http://pusat.baznas.go.id/posko-aceh/baitul-malaceh-bagian-dari-sistem-pengelolaan-zakatnasional/,diaksespada16Agustus2018

https://www.kompasiana.com/ahmadajib07/5dad 33acc0cfa107c540f323/menggali-potensizakat-untuk-kemaslahatan-umat 
Jamaluddin, Y., Fitriani, F., Safrida, S., \& Warjio, W. (2019). Strategi dan Model Pemberdayaan Masyarakat Miskin di Sumatera Utara. Jurnal Administrasi Publik : Public Administration Journal, $9(1)$, 21-30. doi:https://doi.org/10.31289/jap.v9i1.2231

Kamal, S., (2019), Fiqih Zakat dan Teori Kemiskinan. Medan: Perdana Publis.

Kementrian Agama RI, Al-Qur'an dan Terjemahnya,(Bandung, : PT Cordoba Internasional Indonesia, 2012)

Margono, S., (2004), Metodologi Penelitian Pendidikan, Jakarta: Rineka Cipta.

Mustafa, B. (2021). Analisis Peran Pemerintah Daerah dalam Pemberdayaan Usaha Mikro, Kecil dan Menengah di Kabupaten Sidrap. Journal of Education, Humaniora and Social Sciences (JEHSS), 3(3), 1055-1066. doi:https://doi.org/10.34007/jehss.v3i3.488
Nurmiah, N., Kusmanto, H., \& Lubis, Y. (2019). Analisis Kinerja Pemerintah Kelurahan dalam Program Pemberdayaan Kebersihan Kelurahan. Strukturasi: Jurnal Ilmiah Magister Administrasi Publik, 1(2), 176-183. Santifa, M., Warjio, W., Harahap, D., \& Isnaini, I. (2019). Evaluasi Program Pemberdayaan Masyarakat Melalui Bank Sampah Mawar Sejadi di Kelurahan Sijambi Kecamatan Datuk Bandar Kota Tanjung Balai. Strukturasi: Jurnal Ilmiah Magister Administrasi Publik, 1(1), 89-98

Subagio, J., (2004), Metode Penelitian Dalam Teori dan Praktek, Jakarta: PT. Rineka Cipta

Subana, M., \& Sudrajat, (2001), Dasar-dasar Penelitian Ilmiah, Bandung: Pustaka Setia.

Suma, M.A., (2019), Sinergi Fikih \& Hukum Zakat Dari Zaman Klask Hingga Kontemporer, Ciputat: Kholam Publishing.

Undang-UndangNomor23Tahun2011,Pasal1angka2 